\title{
Ursula Hackl. „Das Basler Nationalfonds-Projekt «Quellen zur Geschichte der Phönizier». Ein Forschungsüberblick“
}

\section{Astrid Nunn}

\author{
(2) OpenEdition \\ Journals \\ Édition électronique \\ URL : http://journals.openedition.org/abstractairanica/48297 \\ DOI : $10.4000 /$ abstractairanica.48297 \\ ISBN : 1961-960X \\ ISSN : 1961-960X \\ Éditeur : \\ CNRS (UMR 7528 Mondes iraniens et indiens), Éditions de l'IFRI
}

\section{Référence électronique}

Astrid Nunn, « Ursula Hackl. „Das Basler Nationalfonds-Projekt «Quellen zur Geschichte der Phönizier». Ein Forschungsüberblick“ », Abstracta Iranica [En ligne], Volume 40-41 | 2019, document 26, mis en ligne le 15 juillet 2019, consulté le 17 avril 2021. URL : http://journals.openedition.org/ abstractairanica/48297 ; DOI : https://doi.org/10.4000/abstractairanica.48297

Ce document a été généré automatiquement le 17 avril 2021

Tous droits réservés 


\title{
Ursula Hackl. „Das Basler Nationalfonds-Projekt «Quellen zur Geschichte der Phönizier». Ein Forschungsüberblick“
}

\author{
Astrid Nunn
}

\section{RÉFÉRENCE}

Ursula Hackl. „Das Basler Nationalfonds-Projekt «Quellen zur Geschichte der Phönizier». Ein Forschungsüberblick“ in Hédi Dridi, Danielle Wieland-Leibundgut, Jeannette Kraese (éds.). Phéniciens et Puniques en Méditerranée: l'apport de la recherche suisse/Phönizier und Punier im Mittelmeerraum: ein Beitrag der Schweizer Forschung. Rome : BraDypUS.net communicating cultural heritage, 2017, p. 27-34, (Philainos 2)

L'A, présente un projet sur le rôle des Phéniciens dans les relations entre l'orient et l'occident de la Méditerranée. Toutes les sources écrites sont pertinentes: les inscriptions sur pierre, la céramique, les monnaies ainsi que les textes bibliques, cunéiformes, grecs et latins. La confrontation de ces sources doit aider à comprendre les stratégies appliquées par les Phéniciens pour rester relativement indépendants alors que leurs territoires appartenaient à des royaumes puissants. Leurs petites entités étaient-elles plus flexibles, leur flotte était-elle indispensable, leur culture technique était-elle supérieure, ou encore leur culture mixte les aidait-elle? 


\section{AUTEURS}

\section{ASTRID NUNN}

Université de Munich 